\title{
Oil Palm by Product: How to Compute Its Cost of Production
}

\author{
Drs. Syamsul Bahri, MM, Ak, CA \\ Lecturer of Higher School of Economics "Nusa Bangsa" Medan, North Sumatra Province, Indonesia
}

\begin{abstract}
In order to decide the accurate sales price of the product, it's need to now rationally how to compute the cost of production. It's no problem if the product processing independently. It's not like in the palm oil industry, because of it has two products will out simultanously from the one cycle of processing. From the mill processing of oil palm will be got $C P O$ and $P K$, while their cost combined in one total cost of production, and how it can be compute seperately. One of the two product is CPO as the main product, and another is PK as by-product. There are four methods of computation in cost of production for the two products. But the first two methods and the third are not suitable to be used as the method to compute the cost of production, so that's way it can be used the fourth method to implement as the suitable cost of production computation of PK. The said fourth computation method called as "rendement-based cost of production" for by-product such as PK.
\end{abstract}

Keywords: Cost of production, Crude Palm Oil (CPO), Palm Kernel (PK), computation methods, productive-output based, rendement-based.

\section{Introduction}

In Indonesia as the tropical country has big potential to develop oil palm industry as agribusiness sub-sector. There are also investors and agribusinessmen from Malaysia had involve in oil palm industry in Indonesia.

At the level of processing, production processof palm fruits (Udoh and Essien, 2015)involve de-husking fruits from bunches using a sharp knife. This was followed by boiling the fruits for some hours before it is marshalled. The marshalling is done with the use of a long wooden mortar and pestle or „buried-in“ iron mortar. Before the introduction of the mechanically operated mills system, extraction of palm oil was done manually by squeezing the marshalled (soft) fruits to extract oil. As can be observed, however, the mechanically operated mill system has reduced the stress experienced through manual process. The oil is separated from the hard kernel shell which when cracked will produce kernel nuts. The residue from the de-husked fruits, the milled fruits, and the cracked kernel are being used as firewood for domestic looking.

The company which involve in the oil palm industry should now and aware that there are problem to compute oil palm by product periodically. The product of oil palm is crude palm oil (CPO) as the main product, while palm kernel $(\mathrm{PK})$ as its by product. $\mathrm{CPO}$ as the main product has bigger amount of production cost, and lower cost for PK. Mostly, the company compute the PK cost of production combining with the CPO. So, computation result of production cost insist of CPO and PK. The problem is that we don't know their cost of production respectively, and of course, there are no accurate information to decide the sales price of the products. Even, some company avoid to discuss this problem, and just run the business continously. Actually, in order to decide the rationale of sales price we should now the information of cost of production the product, because of we need the reason of profit percentage from the sale price. In the other hand, to decide the rationale sales price of the product should be based on the cost of the product. 


\section{Objectives}

The aims of this study are as follow :

1. To know how to compute the more rationale cost of production of PK as the by product of oil palm industry.

2. To recommend the company to use more rationale computation for PK cost of production.

\section{Methodology}

This study used descriptive method within to explore and expose the result. The qualitative data got from the literature and the quantitative has taken from company's information and their annual reports, and other relevan information sources from internet web site. Then, based on the relevan data and information, this study came up with the final suitable method to compute the cost of production CPO and PK.

\section{Literature Cited}

The main literature of this study can be used is "cost accounting" and the other are palm oil text book in order to know the characteristic of oil palm and its products. Nowadays, oil palm industry (Syamsul Bahri, 2016) is as the interesting business, especially, among the plantation industries, because of its high average return rate. There are two factors influenced the high average rate of return, namely, cost of production and sales price. From the side of cost of production, there are three variables influenced, i.e. Fixed costs, variable costs, and semi variable costs.

"Cost" (www.dictionary.com) is the price paid to acquire, produce, accomplish, or maintain anything: the high cost of a good meal. "Production" (www.dictionary.com) is the act of producing; creation; manufacture. Cost of production or manufacturing cost (Riwayadi, 2006 ) is the cost related to the function of production. Manufacturing cost consist of raw material, direct labor, and manufacturing overhead cost.

There are three kinds of product can be produced through manufacturing process, namely joint products, main product, and by-product. Joint products is the product which has relative high sales price and produced through joint process together with other products which has relative low sales price.

The oil palm (Corley and Tinker, 2007)is the world's most valuable oil crop. With palm oil production increasing by more than $50 \%$ in the last decade of the twentieth century and set to double in the next twenty years, it has never before been so important to understand the history, use and cultivation of this fascinating crop.

A timely review (Gunston, 2003) of the subject of palm oil, detailing the rapid growth in palm oil availability, its fractionated products (palm stearin and olein), and the increase in production and uses. Provides an account of the past, present and prospective production of palm oil and discusses the growth and production of palm oil fruits and the extraction of crude oil from them. Three sections (Human Food, Animal Feed, and Industrial Uses) review the refining and fractionation of palm oil and consider its many and varied uses.

Oil palm tree produces fruit which called as "fresh fruit bunch (FFB)". FFB could be processed through palm oil mill, then it can produced CPO and PK. So, FFB is the main raw material of CPO and PK. Before starting production of anything(Ram Nivas Saini,2015), materials required must be on hand and that there should be an assurance of its continuous supply to meetproduction needs and to keep up production schedules The computation method of the production cost is based on combined cost of the two products, while it should be separated interm of cost of CPO and PK respectively. The cost accounting information of the product should cleared and informative, and then, of course we need to know the method. From accounting point of view (Riwayadi, 2007), there are two methods can be used to compute production cost of by-product, namely (1) net market value or net realizable value, and (2) net market value recognized (as other income in the income 
statement). In order to compute by-product cost of production, these two methods can be used. Then, these two method can be compared to the two other methods (based on the empirical studies as the training material, Syamsul Bahri, 2014) which called as (3) "the productive-output-based" and (4) "the rendement-based". These the last two methods are practically used by the company.

\section{Cost Structure}

There are two steps within cost of production computation for oil palm products, namely at the raw material level, and manufacturing level.

\section{At the raw material level, it has cost structure to produce FFB as follow :}

1. . Salary and wages

1. . Maintenance

1. . Seeding

1. . Insect and desease control

1. . Fertilizing

1. . Harvest

1. . Transportation to mill

1. . Crops depreciation

2. At the manufacturing product level, it has structure to produce CPO and PK as follow :

2. 1. Salary and wages

2. 2. Chemical

2. 3. Manufacturing tools

2. 4. Laboratory analysis

2. 5. Gasoline and lubricant

2. 6. Electrical power plant

2. 7. Maintenance

2. 8. Insurances

2. 9. Mill depreciation

\section{Cost of Production Computation}

Based on the cost of production which has described above, it can be discussed in this part, about three methods of cost of production for by-product, then continued to analyzed which one method is suitable to implemented in the oil palm industry.

Problem illustration : At the end of May 2016, State Own Enterprise (SOE), Ltd. has run the oil palm industry for one month operationed. The following data (Table 1) can be used as cost of production computation for CPO and PK.

Table 1. Production and Price of CPO and PK May 31, 2016

\begin{tabular}{|l|l|l|l|}
\hline No. & Descriptions & Crude Palm Oil & Palm Kernel \\
\hline 1 & Sales price (RM/MT) & $2,241.50$ & $1,794.75$ \\
\hline 2 & Production (MT and Tonne) & $3,000.00$ & 700.00 \\
\hline 3 & Oil and Kernel Extraction Rate (\%) & 21.00 & 5.00 \\
\hline 4 & Total cost of joint production (RM) & $\mathbf{5 , 7 1 0 , 1 9 8 . 2 2}$ & \\
\hline
\end{tabular}

Notes : Data Source :www.mpob.gov.my as May 2016 and www.kpbptnco.id as May 2016. RM=Ringgit Malaysia, USD 1=RM 4.10. MT=Metric Tonne. Oil and kernel extraction rate are computed based on the amount of FFB. 


\section{Instructions :}

From the above information, compute the cost of production CPO per MT and PK per tonne.

By using the four methods of cost of production for PK, the result are as follow :

1. Net market value or net realizable value.

This method stipulated that the cost of production of PK is RM 1,794.75/MT, it's mean that the cost of production equal to sales price or market value, then it can be used as the contra account or credit for CPO cost of production in the income statement. Actually, it can't be accepted as cost of production of PK as well, because of there is gross profit or loss inside. And the cost of CPO is RM 1,903.40/MT (RM 5,710,198.22 : 3.000 MT). Here, the cost of CPO and PK have not so significant diffference (RM 1,903.40/MT vs RM 1,794.75/MT), and of cource couldn't be used as the reason to decide that PK as by-product.

\section{Net market value recognized as the other income.}

By using this method, cost of production is the same with no. 1 above method, i.e. RM 1,794.75/MT, but the difference is that the market value recognized as other income in the income statement. And the cost of production for CPO is RM 1,903.40 (RM 5,710,198.22 : 3.000 MT). It's mean that the cost of production of PK not so significant different with $\mathrm{CPO}$, so there is no reason to decide that $\mathrm{PK}$ as by-product.

\section{Productive-output-based cost of production computation.}

Productive-output of the product is $3.000 \mathrm{MT}$ of CPO and 700 tonnes of PK. In ratio percentage, CPO has $81 \%$ (3.000 MT : $3.700 \mathrm{MT}$ ) and the rest of 19\% (700 MT : $3.700 \mathrm{MT}$ ) goes to PK. Based on these ratios, the cost of production of CPO per 3.000 MT is RM 4,625,260.56 (81\% x RM 5,710,198.22), while the rest of RM 1,084,937.66 is the cost of production for 700 tonnes PK. Then, cost of production CPO per MT and PK per tonne respectively are RM 1,541.75 (RM 4,625,260.56 : 3.000 MT) and RM 1,549.95 (RM 1,084,937.66 : 700 tonnes). It's mean that the cost of production of PK not so significant different also with CPO, so there is no reason to decide that PK as by-product.

\section{Rendement-based cost of production computation.}

Rendement is the percentage ratio of FFB to become CPO and PK. There are three steps to compute the cost of $\mathrm{CPO}$ and PK.

Step 1. The weighted average computation of $\mathrm{CPO}$ and $\mathrm{PK}$ in percentage :

\begin{tabular}{|c|c|c|c|}
\hline$\underline{O} \& \mathrm{~K} E R$ & $\underline{\text { Sales Price }}$ & Weighted Average & $(\%)$ \\
\hline $\mathrm{CPO}$ & 21 & $2,241.50$ & 470.72 \\
\hline PK & 5 & $1,794.75$ & 89.74 \\
\hline Total & & & 560.46 \\
\hline
\end{tabular}

Step 2. The total cost of production computation of $\mathrm{CPO}$ and PK :

\begin{tabular}{|c|c|c|c|}
\hline \multirow{2}{*}{\multicolumn{2}{|c|}{$\begin{array}{l}\text { Weighted } \\
\text { Average (\%) }\end{array}$}} & \multicolumn{2}{|l|}{ Cost of Production } \\
\hline & & 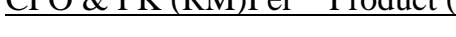 & \\
\hline $\mathrm{CPO}$ & 83 & $5,710,198.23$ & $4,739,464.53$ \\
\hline PK & $\underline{17}$ & $5,710,198.23$ & $970,733.70$ \\
\hline 100 & & $5,710,198$ & \\
\hline
\end{tabular}

Step 3. The unit cost of production computation of $\mathrm{CPO}$ and $\mathrm{PK}$ :

CPO per MT: (Total cost of production of CPO : Total production $) \times$ RM $1=$

$$
:(4,739,464.53: 3,000) \times \text { RM } 1=\underline{\mathbf{R M} 1,579.82}
$$


PK per tonne: (Total cost of production of PK : Total production) x RM 1

$$
:(970,733.70: 700) \times \text { RM } 1 \quad=\underline{\text { RM 323.58 }}
$$

\section{Conclusions And Recommendations}

Based on the above descriptions, it can be concluded the result as follow :

1. Oil palm industry is the interesting business as agribusiness sector especially in the tropical country like Malaysia, Indonesia, and Papua Newgini, because of the price relatively still high, while its cost is relatively low. So if it's compare with other crops, the rate of return of this business relatively higher.

2. There are main product of oil palm industry i.e. CPO, and its by-product is PK.From the model and empirical point of view, there are four methods can be used to compute the PK by-product aside CPO, namely (1) net market value or net realizable value, and (2) net market value recognized (recognized as other income in the income statement), (3) the productive-output-based, and (4) rendement-based cost. The last two methods can be used as the comparable cost of production computation with the first two methods for the PK by-product.

3. To get the rationale and suitable cost of production computation method of oil palm by-product like PK, better if the company in the palm oil industry want to used the fourth method, namely, "the rendement-based cost of production".

\section{References}

[1] Udoh and Essien, Palm Oil Processing and Marketing and Suitable Livelihood in Rural Communities of Akwa Ibom State South-South-Nigeria, International Organization of Scientific Research Journal of Business and Management (IOSR-JBM) e-ISSN: 2278-487X, p-ISSN: 2319-7668. Volume 17, Issue 10 .Ver. II (Oct. 2015), PP 43-50 www.iosrjournals.org.Impact Factor: 1.129, web site : www.iosrjournals.org.

[2] Syamsul Bahri, Analysis of The Suitable and Fair Depreciation Method Selected for Oil Palm Non-Current Asset, International Journal of Education and Research, Vol. 4 No. 2, February, 2016, Impact Factor:0.247, ISSN 2411-5681, web site : www.ijern.com

[3] www.dictionary.com, accessed June 18, 2016.

[4] Riwayadi, Cost Accounting, First edition, Andalas University Press, Padang, Indonesia, 2006.

[5] R.H.V. Corley, P.B. Tinker, The Oil Palm, (Fourth edition, Blackwell Science Ltd., Oxford, United Kingdom, 2003).

[6] F. D. Gunstone, Palm Oil, (Society of Chemical Industry by Willey, Great Britain, 1987).

[7] Ram Nivas Saini, Cost Management \& Cost Control in Chemical Manufacturing Companies of India, International Journal of Research in Management, Economics \& Commerce,Volume 5 Issue 5, May 2015, Impact Factor: 5.662, ISSN 2250-057X, website: www.indusedu.org.

[8] Syamsul Bahri, Inventory Accounting, (Training Material in Enhancement Accounting Skill for Plantation Staff of State Own Companies, 2014).

[9] www.mpob.gov.my, accessed June 18, 2016.

[10] www.kpbptpn.co.id, accessed June 18, 2016. 